E. J. BRILI - PUBLISHER - LEIDEN

\title{
SOME DEPENDENT PEOPLES OF THE SOUTH PACIFIC
}

\author{
BY \\ LINDEN A. MANDER \\ Professor of Political Science, University of Washington
}

xix, 535 pages

Cloth Gld. 26.-

In this book the author portrays the nature of pre-European native society, the effects of European colonization, and the present problems of government in a number of South Pacific countries. The rapid growth of self-consciousness among the dependent peoples has produced a situation which demands as deep an understanding as possible of the factors involved in modern colonial relations.

The book concentrates on a few of the native populations of the South Pacific instead of dealing more generally with many groups. While the number of native inhabitants in the six countries does not total more than perhaps two million, of whom over one-half are in Papua-New Guinea, each area offers unique problems and more is to be gained by considering the difficulties at close range than by dealing more generally with situations over a wider area. The peoples selected for discussion are the New Zealand Maoris, the inhabitants of Western Samoa, the Australian Aborigines, the natives of PapuaNew Guinea, and the aboriginal peoples of the British Solomon Islands, Tonga, Fiji, and the New Hebrides.

The chapter on Western Samoa analyzes the extremely complex psychological and cultural factors in that region and indicates the 
significance of New Zealand's action in following the major recommendations of the United Nations Commission which visited Samoa in the latter part of 1947.

In Australia tragedy resulted in a country where the lack of food and water in a large part, as well as psychological factors, quickly wrought havoc with the Aborigines.

Papua-New Guinea represents the largest problem. The peculiar interest of this country lies in the recent developments of policy; since I945 the Australian government has initiated far-reaching plans.

The British Solomon Islands represent a typical British crown colony administration in an isolated area, although of course technically the islands are designated a protectorate.

Tonga is worthy of study because of the happy blending of native and western influences largely owing to the enlightened leadership of its monarchy.

The special interest of the Fiji Islands derives from the problems raised by the juxtaposition of three racial groups, white, Indian, and Fijian, the rapid increase in the population and the claims of the Indian group.

The New Hebrides was selected because it afforded and example of a condominium, or joint rule, by France and Great Britain. Unfortunately the story is one of almost unbelievable ineptitude.

The final chapter describes some of the earlier proposals to establish sume form of regional organization, the work of the Central Medical School at Fiji, the High Commission of the Western Pacific, the South Pacific Health Service, the South Pacific Regional Commission and estimates the possibilities of international cu-operation in the field of administering dependent peoples.

MEDE VERKRIJGBAAR DOOR BEMIDDELING VAN DE BOEKHANDEI 